\title{
Midwestern Writers on Environmental Stewardship: A Review Essay
}

\author{
REBECCA CONARD
}

A Sugar Creek Chronicle: Observing Climate Change from a Midwestern Woodland, by Cornelia F. Mutel. A Bur Oak Book. Iowa City: University of Iowa Press, 2016. xv, 251 pp. Sources of information on climate change, bibliographic essay, index. $\$ 16.00$ paperback.

The Big Marsh: The Story of a Lost Landscape, by Cheri Register. St. Paul: Minnesota Historical Society Press, 2016. 272 pp. Maps, illustrations, notes. \$17.95 paperback.

MY BEST CHRISTMAS GIFT this past year was time to read A Sugar Creek Chronicle: Observing Climate Change from a Midwestern Woodland and The Big Marsh: The Story of a Lost Landscape. Those reading and reflecting hours coincided with the presidential transition, from an administration that made environmental stewardship a priority to one that is led by a climate-change skeptic who is hostile to environmental regulation. Now more than ever, as these two books demonstrate, we need to cultivate an environmental ethic with roots as deep as a tallgrass prairie.

In A Sugar Creek Chronicle, ecologist Cornelia Mutel takes readers into her world, in and around the woodland acreage along Sugar Creek north of Iowa City where she and her husband live and raised a family. This is an intimate book, one in which Mutel brings the weight of her scientific knowledge about climate change, her talent as a science writer, and her personal

THE ANNALS OF IOWA 76 (Spring 2017). C State Historical Society of Iowa, 2017. 
concern as a parent and grandparent to make the profound gravity of climate change understandable to a general audience. She "invites" readers "to consider the importance of climate change and to realize that we can-indeed that we must-rapidly take action to limit its expression" (x). This understated call to action sets the book's tone.

In structure, the book is modeled on the familiar annualcycle-of-nature essay style that Aldo Leopold introduced in $A$ Sand County Almanac. Mutel weaves two narratives in alternating chapters. One is a "Weather and Climate Journal" of the year 2012 - "perhaps the first year that the reality of climate change came home to the American public" (xi). The other narrative is a "Memoir" in which she reflects on the stages of her life and her maturation as an ecologist in relation to the development of environmentalism.

In each season of the "Weather and Climate Journal," Mutel addresses different aspects of climate change in the form of dated journal entries, and she does so in non-scientific language. In "Winter," for instance, she unpacks the fundamental problem of climate change-" "human-induced increases in heat-trapping gases in the atmosphere" - and the resultant greenhouse effect (18). She also notes that the greenhouse effect is not a new concept; scientists first observed and named the process in the midnineteenth century. In "Spring," to take another example, she tackles the distinction between climate and weather, explaining how the gradual but relentless rise in average global temperature affects all natural processes but particularly the "way water cycles over and through Earth's surface." Again, she cuts to the heart of the matter: "More of each year's precipitation is falling in winter and spring, while summer and fall are becoming drier," and weather events are both more extreme and less predictable (56). In each of the seasonal chapters, she mixes observations of the natural world around her with information and commentary on climate change. One can easily imagine what a walk in the woods would be like with Connie Mutel.

In the "Memoir" chapters, which are shorter, Mutel takes us on a more personal odyssey. She begins at the beginning, with her childhood in the 1940s and '50s, when consumer consumption patterns placed less overall stress on the environment. Her 
mother's premature death from cancer, which came just as the author was starting college, "awakened" her to the fragility of life and how quickly it can slip away. Her college and university years, "Learning, 1965-1975," coincided with the flowering of the modern environmental movement, which gave greater import to her studies in biology and plant ecology. In "Mothering, 19761997," we learn that concern for the environment influenced the decisions she and her husband made about where and how to live as they raised a family of three boys. Mutel pairs thoughts on parenting, as well as her first bout with cancer, with observations on a succession of environmental wake-up calls that came during those two decades: the energy crisis, discovery of the ozone hole, and growing concern about the extent of acid rain. "Stilling, 1997-2012" is even more reflective, as Mutel introduces readers to her grandchildren and assesses the status of environmental problems that will affect their lives.

While the interwoven narratives of A Sugar Creek Chronicle flow gently, Mutel does not end on a particularly hopeful note. A short concluding chapter recaps the major weather catastrophes of 2012-2013 and summarizes the latest findings of climate scientists as presented in the Fifth Assessment Report of the Intergovernmental Panel on Climate Change. She notes that despite continued and intensifying warnings from climate scientists, the 2013 United Nations Climate Change Conference "made little progress" toward curbing greenhouse-gas emissions globally (206-9). As the book was going to press in 2015, Mutel added another short chapter in which her urgency becomes more palpable. We are rapidly approaching the critical hour of decision: either do little or nothing, which will mean that more and more resources will be required to cope with the consequences of a climate that is increasingly uncontrollable, or take measures that will slow the rate of climate change and minimize its adverse effects.

CHERI REGISTER'S The Big Marsh is equally personal but more historical in its approach. Her intent, as she states at the outset, is to figure out "how personal stories intersect with public history" in a belief that "the deeper we probe the personal, the more likely we are to achieve universal resonance." In her case, the personal is Freeborn County, Minnesota, where her family has "a six- 
generation claim on the landscape" (16). Register's great-greatgrandparents Robert and Mary Speer, Yorkers of Dutch and English ancestry, were among the first group of white settlers to arrive in Moscow Township of Freeborn County in 1855. Another line of descent comes from Henry N. and Sarah Ostrander, also Yorkers, who arrived in 1859 and settled west of the marsh in Bancroft Township.

Freeborn County sits on the Minnesota-Iowa border, and the big marsh that is the subject of Register's book is a wetland created by the Wisconsin Glacier. On the historic "pre-drainage" landscape, the marsh stretched south and east from Lake Geneva to cover large parts of four townships that lay northeast of the intersection of modern Interstates 90 and 35. Before Euro-Americans arrived, the Dakota, Sauk, and Meskwaki shared hunting and gathering space in and around the big marsh. An 1835 mapping expedition under the direction of Albert Miller Lea and an 1854 public land survey began the process of transforming the shared land-use practices of native peoples into measured land divisions that could be bought and sold, with land use determined by individual landowners. As part of that transformation, native peoples were cajoled or forced onto increasingly smaller tracts and gradually moved west and south to make room for more white settlers.

Register points to 1877 as a watershed year, so to speak. In that year the Minnesota legislature passed the first of multiple laws authorizing local governments to make decisions regarding proposals to drain wetlands. Two years later, the St. Paul and Manitoba Railroad, a predecessor of the Great Northern, submitted its first proposal for a massive drainage project in the Red River's floodplain. At about the same time, Euro-American settlement around the big marsh reached a plateau. Register found no particular evidence that those living around the marsh considered the wetland to be a hindrance or bother. To the contrary, abundant fish and wildlife provided farmers ample means to supplement farm production. This was because the Southern Minnesota Railroad, which owned much of the marsh, was in no hurry to sell the land. In the absence of a resident landowner to prohibit or impose restrictions on fishing, hunting, and trapping, the marsh continued to function as a commons, although the indigenous users had been supplanted by Euro-American farmers, 
gentlemen sport hunters, and commercial hunters supplying markets in Chicago and elsewhere.

Drought conditions and a series of prairie fires that began in 1889 eventually destroyed thousands of acres of peat and timber lands in the marsh. Then, anticipating a long-term loss of land value, the Southern Minnesota Railroad began to sell its holdings, but not to ordinary farmers. Urban capitalists saw an opportunity to profit from large-scale farming. Among them were Minneapolis realtor Putnam Dana McMillan and his brother-in-law, Albert Hastings, who purchased 6,000 acres and proceeded to drain about 3,000 acres of the marsh to create Ricelawn Ranch, operated by hired workers under the supervision of a farm superintendent. In 1898 McMillan, having purchased Hastings's interest, sold the undrained half of his land to another syndicate, which intended to subdivide the land and sell the tracts for farming.

Three years later, 21 landowners presented a petition to the Freeborn County Board of Commissioners calling for the construction of a major drainage ditch, at public expense, claiming, as required under Minnesota water law, that it would be of "public benefit and utility." Their petition provoked an organized public backlash. Opponents managed to block the project until 1907, when, thanks to some clever legal maneuvering, proponents finally prevailed in court. By November 1909, the big marsh had been transformed into arable land, drained by a 17.7-mile main channel, 65 feet wide and 12 feet deep, fed by nine laterals, all of which directed water more swiftly to the Cedar River.

The fight to stop the drainage project - and the consequences of that failure-is the central drama of The Big Marsh. Register relates that drama in an engaging narrative that weaves through the lives of the principal actors as well as those of her own family. Among the more outspoken opponents of draining the marsh was Register's great-grandfather Elbert Ostrander, who in later decades would operate his farm as a kind of halfway house for parolees from Red Wing Reformatory and, during the Great Depression, lobby the state legislature for a moratorium on farm foreclosures. She is careful to point out, however, that "it would be anachronistic to read the popular resistance to the Riceland- 
Moscow ditch in terms of twenty-first-century wetland preservation" because "early conservationists had only a dawning sense of ecology" (156).

In the bigger picture, Register hypothesizes that drained wetlands are part of the "geography of westward migration," by which she means they represent the triumph of entrepreneurs like P. D. McMillan over "yeoman farmers ... with simpler ambitions to live securely on land they worked themselves" (211-12). If she had delved more deeply into these competing land-use "visions," she likely would have found that "yeoman farmers" themselves held deeply divided opinions on the benefits of drainage. Instead, she ends on a note of redemption. We learn that P. D. McMillan and his heirs became generous patrons of fine art and education, always for public benefit, primarily through the Minneapolis Institute of Art. Finally, she takes us with her to the 2013 dedication of a wildlife management area in Freeborn County, roughly 850 acres in the northern reach of the former big marsh where the Minnesota Department of Natural Resources is restoring some semblance of the pre-drainage landscape.

This is not a story that places climate change front and center, as A Sugar Creek Chronicle does, but it does implicate "the continued tiling and ditching, the dwindling of underground aquifers, and the practice of plowing fields bare in the fall with no stubble to hold the soil in place" in the land's declining ability to mitigate weather extremes (58). In this sense, Register exposes the complexity of human actions that are undermining the earth's ability to regenerate. She does not acknowledge writers who have influenced her, but there are echoes of William Cronon's masterful explication of land commodification in Indians and the Land: Indians, Colonists, and the Ecology of New England and William Least Heat-Moon's perambulation around the topographic quadrants of Chase County, Kansas, in PrairyErth: A Deep Map.

The Big Marsh is nicely illustrated with maps and photographs. Source notes, however, are in the form of unnumbered endnotes referenced by page. For those who pay attention to footnotes, the author's penchant for short chapters facilitates note reading to a degree, but an added frustration is the lack of 
an index. A Sugar Creek Chronicle includes an index but no footnotes. Mutel compensates for the latter with a chapter-by-chapter bibliographic essay.

FAMILY is a secondary theme of both books, although the authors' perspectives differ. Register examines her forebears, seeking to understand how they valued the natural environment during a time of rapidly intensifying land cultivation. Mutel's eye is on the next generation, first as a parent consciously instilling a sense of wonder in and respect for nature in her three sons, then as a grandmother laying a trail of environmentalist breadcrumbs for her grandchildren.

Each author in her own way urges more active environmental stewardship on a personal level. Mutel is more explicit in her belief that if enough people would take the environmental consequences of climate change to heart, then we humans, individually and collectively, would take appropriate actions to slow the environmental degradation and ecological destruction that is taking place all around us. Toward that end, she provides an annotated list of sources where one can find more information about climate change.

As a public historian with a strong interest in local history, I think we need more books, exhibits, and public programs that draw on family and local history for environmental education, raising awareness about climate change and its consequences, and continually urging individuals to live by an environmental ethic. Climate-change scientists are repeatedly treated as modernday Cassandras, in part because the language of science is dense and the human causes of climate change are complex. Connie Mutel and Cheri Register have given us two books that deserve wide reading and will, I hope, stimulate more works that focus on real people in relation to actual environments. These are stories we all can comprehend and that allow audiences a measure of freedom in formulating their own ideas. 